\title{
The Effects of Non-Cash Transactions on Consumer Satisfaction (A Case Study on Consumers of the Oro-Oro Dowo Market, Malang)
}

\author{
Ary Bakhtiar ${ }^{*}$, Harpowo ${ }^{1}$, Rahmad Pulung Sudibyo ${ }^{1}$, Amanina Nur Fitria ${ }^{1}$, Wahid Muhammad \\ Shodiq ${ }^{2}$ \\ ${ }^{1}$ Department of Agribusiness, Faculty of Agriculture and Animal Science, University of Muhammadiyah \\ Malang, Jalan Raya Tlogomas, 246, Malang, East Java, Indonesia \\ ${ }^{2}$ Master of Agribusiness, Postgraduate Program, University of Muhammadiyah Malang, Jalan Raya \\ Tlogomas, 246, Malang, East Java, Indonesia
}

Received: 13 February 2021; Revised: 18 October 2021; Accepted: 29 October 2021

\begin{abstract}
The Internet of think is considered incredibly adaptable in the present digital world, one of which is noncash payments, making it easier, faster, and decreasing human errors. It is not surprising that the government is now promoting Gerakan Nasional Non-Tunai (GNNT) program by ratifying a new application owned by one of the BUMN subsidiaries to enable payment transactions. The GNNT is now being encouraged in many sectors of Indonesian needs, including traditional markets. The objectives of this study were: 1) identifying the consumer characteristics who uses non-cash payment applications in OroOro Dowo market Malang, and 2) investigating the impact of service quality, product image, and promotion on consumer satisfaction as non-cash payment application users. The research site was in Oro-Oro Dowo market, Malang. It is the first traditional market to employ non-cash payments as a payment option, with the research period beginning in April 2020. This study had 100 participants selected through the distribution of questionnaires. The data analysis employed Partial Least Squares-Structural Equation Modeling. The findings showed that the majority of respondents who use non-cash applications were female consumers (76\%), had an average age of 20-25 years (47\%), had undergraduate education (46\%), worked as private employee (37\%), and had an average income of $<\mathrm{Rp} 2.000 .000(37 \%)$. The path coefficient test revealed that product image and promotion variables had a significant effect on consumer satisfaction as they had a sig value of $>0.05$ while the application service variable had a sig value greater than 0.05 , it had a negligible effect on consumer satisfaction.
\end{abstract}

Keywords: consumer; characteristics; transaction; path; coefficient

\section{How to cite:}

Bakhtiar, A., Harpowo, Sudibyo, R. P., Fitria, A. N., \& Shodiq, W. M. (2021). The Effects of Non-Cash Transactions on Consumer Satisfaction (A Case Study on Consumers of the Oro-Oro Dowo Market, Malang). Habitat, 32(3), 154-162. https://doi.org/10.21776/ub.habitat.2021.032.3.17

\section{Introduction}

People in the digital era must be competent in integrating creative parts of life in many disciplines. It demonstrates that society, indeed, contributes to the advancement of a more modern era. The growth of the financial technology (fintech) industry has also inspired the formation of startup companies that use the Internet of Think as a digital financial sector driver. The Internet of Think comprises all acts that are occurred via the

${ }^{*}$ Correspondence Author.

E-mail: arybakhtiar@umm.ac.id

Phone: +62 821-4084-1550 internet in which actors engage each other. The example of the use of the Internet of Think in many activities are online transportation, ecommerce, online ticket reservations, live streaming, e-learning, and other tools to aid in specific fields such as remote temperature sensors, GPS tracking, and so on that use the internet or network as a medium. The numerous benefits of the Internet of Think make life easier. Specifically, it is critical for carrying out all duties utilizing a systematic and efficient approach in economics (Junaidi, 2015).

Electronic Commerce (E-Commerce) refers to the use of the Internet of Think for payment transactions. E-commerce can take place between 
businesses and consumers, and it includes the use of the Internet and the World Wide Web to offer items and services to consumers. In Indonesia, the use of e-commerce is growing. The increasing number of entrepreneurs who use e-commerce for their businesses illustrates the importance of using the internet for business transactions. Electronic commerce is the use of communication networks and computers to carry out business processes. The definition of e-commerce is using the internet and a computer with a web browser to introduce, offer, buy and sell products. One of the benefits with the implementation of e-commerce is that a company can create an international market. Businesses can be run without needing to cross national borders with the use of digital technology. Operational costs can be kept as low as practicable. Reduce the risk of human error by shortening processing time. Reduce the paper usage in numerous job activities such as design, production, shipping, distribution, and marketing.

One of the purposes of e-commerce is that, as modern technology for non-cash payments, both locally and internationally, it has evolved rapidly, accompanied by different advances that make its use more efficient, secure, fast, and convenient. People's lifestyles are changing as a result of technological advancements, which tend to be consumptive. Many changes have occurred in the economy, security, culture, and education due to the rapid development of technology and information. A large amount of money in circulation, the prevalence of counterfeiting cases, and the high operational costs incurred by Bank Indonesia each year to print, store, distribute, and destroy money are the impetus for Bank Indonesia, as Indonesia's central bank, to launch a movement to use non-cash instruments (Less Cash Society/LCS), particularly in conducting economic transactions, known as BNNT. Bank Indonesia Regulation Number 11/12/PBI/2009, as one of the supporters of Bank Indonesia's mission to create a less-cash society in Indonesia, prompted the development of E-money. People in the digital era must use ease and effectiveness for their convenient interaction. Digital innovation in many disciplines demonstrates that society, too, contributes to the growth of a more modern period (Maulana et al., 2015).

E-money is a service in which users do not need to use cash to make transactions. It uses money previously placed in the agency that provides this service. E-money has various advantages in terms of time and energy savings because users do not need to carry currency and may avoid blunders or mistakes when delivering change. With the advancement of time and technology, more and more changes occur in daily life, one of which is the usage of electronic money, which eliminates the need for individuals to carry paper money. Paper money has now been digitalized money. After Bank Indonesia released the regulations included in Bank Indonesia regulation Number 20/6/PBI/2018 concerning the electronic money, the enactment and implementation of electronic money became lawful. Currently, BI guarantees that the payment system runs smoothly, either in cash or non-cash transactions. BI reported a significant growth in the use of electronic money. There are two kinds of electronic money. The first sort of electronic money is chip-based money (E-money, Flazz, and Brizzi). The second type of electronic money is server-based (Go-pay, OVO, DANA, and LinkAja!). The non-cash application is a serverbased program designed to replace $\mathrm{T}$-cash nationalized by the government in response to the Minister of BUMN's circular letter SE$3 / \mathrm{MBU} / 08 / 2019$. Non-cash is a financial technology solution developed in collaboration with the Association of State-Owned Banks/HIMBARA, Telkomsel, and Pertamina. Non-cash is a collection of digital money services for BUMN.

The government is currently promoting non-Cash applications as a national transaction tool in many payment sectors. Nowadays, nonCash payments can be used not only by BUMN but also by conventional and modern markets. Through the market service, The Ministry of Trade under the auspices of BUMN encourages non-Cash applications as a means of payment in pilot markets in several big cities. Malang City is one of the places targeted for the use of non-Cash applications. The Oro-Oro Dowo Market Malang is the first modern pilot market to begin using the non-Cash application. It begins from several complaints of customers or market consumers who are unable to find change, as well as government programs that want to have a virtual payment application that is under development and needs of today's society and can change financial inclusion with non-cash transactions in Indonesia from $50 \%$ to $75 \%$ by the end of 2019 .

The main reason why this research took Oro-Oro Dowo market Malang as the research site is that it is an active market and the first modern pilot market in Malang City. The Oro-Oro Dowo 
Market Malang is the first market in Malang City to have a non-cash payment application installed. All merchant installations at the Oro-Oro Dowo Malang market were completed in March 2020, coinciding with the Covid-19 pandemic's arrival in Indonesia. The COVID-19 pandemic is one of the factors that has sharpened the focus of non-cash payment applications users. People are increasingly using non-cash payment instruments because they feel that non-cash payments are safer to use and do not come into direct contact with cash which contains a lot of bacteria and viruses that may be one of the causes of the spread of the COVID-19 virus (Tazkiyyaturrohmah, 2018). This study aims to determine: (1) the characteristics of respondents as non-cash applications users at the Oro-Oro Dowo market Malang; and (2) the effect of service quality, product image, and promotion on consumer satisfaction at the Oro-Oro Dowo Market Malang.

\section{Theoretical Underpinning}

Cash is a payment mechanism that is still widely used today. Non-cash payment methods, on the other hand, are fast evolving and have a huge potential to speed up the transaction process in the 5.0 era. This condition is considered to make it easier for consumers to choose various payment methods for products or services according to their wishes and needs (Swiecka et al., 2021). The theory of diffusion (Rogers, 1995) serves as the theoretical foundation for this study, as it plays a significant role in the adoption of numerous technologies, including electronic payments. This is inseparable from the view of diffusion theory which states that various innovations will be easily accepted by consumers if they can increase the use of goods or services. One has to do with non-cash or digital payment developments.

Various previous studies have revealed that cash payments still dominate (Esselink \& Hernández, 2017; Harasim \& Klimontowicz, 2017). According to Kalckreuth et al. (2014) 85 percent of consumers prefer cash payments due to security, convenience, cost, and speed. In line with Swiecka \& Grima (2019) which states that the choice of consumer payment methods is closely related to convenience, speed, and security.

Non-cash payment innovations offer a number of benefits, including quick transactions and the ability to conduct business anywhere and at any time (Polasik \& Piotrowski, 2016). One of them is the use of non-cash payments that can be made via smartphones (Gong et al., 2020; Zhou, 2013). Consumer behavior towards payment options is supposedly changing as a result of economic changes (Swiecka et al., 2021). This condition will affect the knowledge, awareness, and readiness, and ability of consumers to adopt new payment methods. All forms of change, however, necessitate a process of adaptation (Purnomo et al., 2021). Based on the various results of previous studies, it is important to research consumer satisfaction with various noncash payment services.

\section{Research Methodology}

The study was conducted at Oro-Oro Dowo market Malang. This market was chosen using a purposive sampling strategy since it is the first buying and selling place in Malang that already applies the non-Cash application as a mode of payment for buying and selling activities. The data was collected in April 2020. The study relied on primary data collected via questionnaires and interviews. The sample was determined through accidental sampling (Rifai, 2015), with a total sample of 100 respondents used in the study.

This study employed three variables $\mathrm{X}$ and one variable $\mathrm{Y}$, where the $\mathrm{X}$ variables were Service Quality (X1) (Suminar, 2017), Product Image (X2) (Tangguh et al., 2018; Windiana at al., 2020), and Promotion (X3) (Lenzun et al., 2014), while the Y variable was Consumer Satisfaction. Service quality relates to non-cash payment applications features and merchants. Product image pertains to consumer mindset and trust. Promotions refers to discounts, and product promotion methods (social media). Consumer satisfaction refers to the level of quality recognized by consumers and the loyalty of noncash application users. This study used PLS-SEM (Partial Least Square Structural Equation Modeling) analysis. PLS-SEM analysis was employed to discover the multivariant analysis approach that may be applied to characterize the simultaneous linear relationship between variables that can be measured directly (indicators) and variables that cannot be measured directly (latent variables) (Sholiha \& Salamah, 2015). Before starting data analysis, the first step was to determine whether the data acquired from filling out the questionnaire is valid using a validity test with a significance level of 0.05 or $5 \%$ and reliability if it gives a Cronbach Alpha value more than 0.60 . It was proceeded by model measurement (outer model), model structure (inner model), and hypothesis testing (Garson, 2016; Hair et al., 2011; Hair et al., 2014). 


\section{Results and Discussion}

\subsection{Respondent Characteristics}

Based on the findings of interviews and the distribution of questionnaires to 100 respondents, the following are the characteristics of respondents.

Table 1. Respondent Characteristics

\begin{tabular}{llc}
\hline Gender & Category & $\begin{array}{c}\text { Respondent } \\
\text { Percentage }\end{array}$ \\
\hline \multirow{3}{*}{ Age } & Male & 76 \\
& $<20$ & 24 \\
\hline \multirow{4}{*}{ Education } & $20-25$ & 8 \\
& $26-30$ & 47 \\
& $>30$ & 40 \\
& High School & 5 \\
& (SMA/SLTA) & 38 \\
& Diploma & 12 \\
& Bachelor/S1 & 46 \\
Job & S2/S3 & 4 \\
\hline \multirow{5}{*}{ Income } & Student & 25 \\
& Civil Servant & 3 \\
& Private & 37 \\
& Employee & 14 \\
& Entrepreneur & 21 \\
\hline & Others & 30 \\
& $<2.000 .000$ & 34 \\
& $2,000.000-$ & \\
& 4.000 .000 & 28 \\
& $4.000 .001-$ & 8 \\
\hline
\end{tabular}

Table 1 demonstrates that the majority of non-cash consumers were women. Women had a significant percentage because the majority of the women who buy in Oro-Oro Dowo market Malang are looking for clothing, housing, and food. This finding is in line with (Shin et al., 2019; Shodiq et al., 2020), stated that women have higher resistance to family consumption, making them dominant in food choices. Meanwhile, men's non-cash transactions are mainly for recreational purposes, such as paying for coffee at a cafe or purchasing mobile phone credit.

The majority of consumers that make transaction payments using non-cash applications were between the ages of 20 and 25 since that age group is more willing to accept new technology in the efficiency of everyday life transactions. This finding contradicts to (Roberts, 1996), who claimed that elderly consumers are more interested than younger consumers. However, the findings of this study are in line with (Schubert et al., 2010), who indicated that young consumers are more sensitive to a change. The age range of 26-30 was the second-largest since this productive age group is also acquainted with non-cash payment transaction techniques. The age range under 20 years had a relatively low percentage since it only follows the trend, while the age range above 30 years had the lowest number because conventional methods that are still relevant in today's world dominate daily life.

Most consumers who make transaction payments using non-cash applications had a bachelor degree, worked as employees and housewives due to their openness to technological changes. These findings are in line with (Meyer, 2015; Shodiq et al., 2020), who indicated that someone with higher education is more sensitive to a change. The second-largest percentage of consumers were from high school education dominated by students to meet dynamic and fastpaced demands. The third-largest percent came from diploma education, while the last was education at the S2/S3 level, dominated by ages above 30-35 years because of a ball of thinking that still puts forward the conventional way and high income.

Based on the type of job, most consumers who make payment transactions using non-cash applications were private employees, because they need to fulfill fast-paced needs. The second highest percentage was consumers who are still learning to follow the trend of functional payments. For consumers whose jobs are entrepreneurs, the percentage was still quite high. Civil servants (PNS) had a fairly low percentage of $3 \%$ and other fields by $21 \%$ due to the fulfillment of transaction activities. Most consumers who use electronic money were from the middle to upper-middle classes and technologically literate (Maulinda, 2016).

Based on the income, the majority of consumers who use non-cash applications had an income of Rp. 2.000 .000 - Rp. 4.000 .000 (34\%). An income range of Rp. 2.000.000 had a proportion of $30 \%$. An income range of $\mathrm{Rp}$. 4.000 .001 - Rp. 6.000.000 had a proportion of $28 \%$, and income > Rp. 6.000 .000 had a proportion of $8 \%$. The more you observe the evolution of non-cash transactions, the more you will notice them being used. 


\subsection{Instrument Test}

In this study, the instrument test employed validity and reliability (Widi, 2011). Tests were carried out on 35 responders to determine whether the designed research instrument was sufficiently capable of producing results that corresponded to field conditions. The test results concluded that all of the research instruments' data were legitimate and reliable. This quality showed that the produced research instrument was reliable and ready for further testing.

\subsection{The Outer Model}

The next step is evaluating the outer model through 3 criteria: convergent validity, discriminant validity, and composite reliability. Here is the analysis.

\subsubsection{Convergent Validity}

Examining the loading factor value reveals convergent validity. The convergent validity test aims to determine the relationship between the indicator and construct scores. If the loading factor value is greater than 0.05 , the construct is said to be convergent (Rifai, 2015; Solimun et al., 2017).

Table 2. Loading Factor Value on Convergent Validity test

\begin{tabular}{|c|c|c|}
\hline Indicator & Loading Factor & Notes \\
\hline $\begin{array}{l}\mathrm{X} 1.1 .1 \text { to } \\
\mathrm{X} 1.1 .6\end{array}$ & $0,604-0,844$ & \\
\hline $\begin{array}{c}\mathrm{X} 1.2 .1 \text { to } \\
\mathrm{X} 1.2 .6\end{array}$ & $0,539-0,773$ & \\
\hline $\begin{array}{c}\mathrm{X} 2.1 .1 \text { to } \\
\mathrm{X} 2.1 .6\end{array}$ & $0,511-0,751$ & \\
\hline $\begin{array}{c}\mathrm{X} 2.2 .1 \text { to } \\
\mathrm{X} 2.2 .6\end{array}$ & $0,506-0,662$ & $\begin{array}{l}\text { It fulfilled the } \\
\text { convergent }\end{array}$ \\
\hline $\begin{array}{c}\text { X3.1.1 to } \\
\text { X3.1.6 }\end{array}$ & $0,530-0,839$ & (loading factor $>$ \\
\hline $\begin{array}{c}\mathrm{X} 3.2 .1 \text { to } \\
\text { X3.2.6 }\end{array}$ & $0,510-0,630$ & \\
\hline $\begin{array}{c}\text { Y1.1 to } \\
\text { Y1.6 }\end{array}$ & $0,537-0,788$ & \\
\hline $\begin{array}{c}\text { Y2.1 to } \\
\text { Y2.6 }\end{array}$ & $0,515-0,620$ & \\
\hline \multicolumn{3}{|c|}{$\begin{array}{l}\text { Source: Primary Data, } 2020 \\
\quad \text { According to the test results, all research } \\
\text { indicators met the convergent validity criteria. The } \\
\text { test can proceed to the next stage as the } \\
\text { assumption of convergent validity was fulfilled. } \\
\text { Table } 2 \text { above displays the convergent validity } \\
\text { value. }\end{array}$} \\
\hline
\end{tabular}

\subsubsection{Discriminant Validity}

The discriminant validity can be seen in the cross-loading value. The discriminant validity test is used to check that each construct is distinct from other variables. A variable has discriminant validity if its cross-loading value is greater than the cross-loading of other variables (Garson, 2016; Solimun et al., 2017). Table 3 below displays the cross-loading value.

Table 3. Cross Loading Value on Descriminant Validity Test

\begin{tabular}{ccccc}
\hline Indicator & $\mathbf{X 1}$ & $\mathbf{X 2}$ & $\mathbf{X 3}$ & $\mathbf{Y}$ \\
\hline $\mathrm{X} 1.1 .1$ to & 0,604 & $-0,251$ & $-0,313$ & 0,014 \\
$\mathrm{X} 1.1 .6$ & to & to & to & to \\
& 0,844 & 0,473 & 0,204 & 0,287 \\
$\mathrm{X} 1.2 .1$ to & 0,539 & $-0,333$ & $-0,251$ & $-0,187$ \\
$\mathrm{X} 1.2 .6$ & to & to & to & to \\
& 0,773 & 0,232 & 0,177 & 0,093 \\
\hline $\mathrm{X} 2.1 .1$ to & $-0,298$ & 0,511 & $-0,129$ & $-0,190$ \\
$\mathrm{X} 2.1 .6$ & to & to & to & to \\
& 0,350 & 0,751 & 0,340 & 0,056 \\
$\mathrm{X} 2.2 .1$ to & $-0,132$ & 0,506 & $-0,241$ & $-0,235$ \\
$\mathrm{X} 2.2 .6$ & to & to & to & to \\
& 0,160 & 0,662 & 0,258 & 0,150 \\
\hline $\mathrm{X} 3.1 .1$ to & $-0,312$ & $-0,134$ & 0,530 & $-0,194$ \\
$\mathrm{X} 3.1 .6$ & to & to & to & to \\
& 0,303 & 0,133 & 0,839 & 0,165 \\
$\mathrm{X} 3.2 .1$ to & $-0,295$ & $-0,162$ & 0,510 & $-0,190$ \\
$\mathrm{X} 3.2 .6$ & to & to & to & to \\
& 0,396 & 0,366 & 0,630 & 0,143 \\
\hline \multirow{2}{*}{$\mathrm{Y} 1.1$ to } & $-0,426$ & $-0,426$ & $-0,014$ & 0,537 \\
$\mathrm{Y} 1.6$ & to & to & to & to \\
& 0,183 & 0,333 & 0,136 & 0,788 \\
\hline $\mathrm{Y} 2.1$ to & $-0,184$ & $-0,312$ & $-0,450$ & 0,515 \\
$\mathrm{Y} 2.6$ & to & to & to & to \\
& 0,505 & 0,234 & 0,318 & 0,620 \\
\hline
\end{tabular}

Source: Primary Data, 2020

Based on Table 3, it can be concluded that all indicators had a cross-loading value on a construct that was bigger than the cross-loading of other variables. These findings implied that the variable had discriminant validity, and the test can be proceeded.

\subsubsection{Reliability Test}

The construct reliability test was measured using two criteria: composite reliability and Cronbach's alpha. A construct is considered reliable if the composite reliability value is greater than 0.70 and Cronbach's alpha is greater than 0.70 (Garson, 2016; Putra, 2015; Solimun et al., 2017). 
The values of composite reliability and Cronbach's alpha are provided in Table 4.

Table 4. The Values of Composite Reliability and Cronbach's Alpha on Reliability Test

\begin{tabular}{lcc}
\hline \multicolumn{1}{c}{ Category } & $\begin{array}{l}\text { Cronbach's } \\
\text { Alpha }\end{array}$ & $\begin{array}{l}\text { Composite } \\
\text { Reliability }\end{array}$ \\
\hline Service Quality & 0,760 & 0,765 \\
Product Image & 0,831 & 0,777 \\
Promotion & 0,796 & 0,720 \\
Consumer & 0,845 & 0,799 \\
Satisfaction & &
\end{tabular}

Source: Primary Data, 2020

As shown in Table 4, Cronbach's Alpha and Composite Reliability on each variable are greater than 0.70. In short, the four variables can be considered to be reliable. The test can be performed based on these findings.

\subsection{The Inner Model}

\subsubsection{Determinant Coefficient $\left(R^{2}\right)$}

The determinant coefficient is used to illustrate how much influence (Bayu et al., 2020; Bayu et al., 2020; Marphy \& Priminingtyas, 2019) the independent variables (X1, X2, and X3) have on the dependent variable (Y). The following table demonstrates the value of the determinant coefficient.

Table 5. R-Square Value (Determinant Coefficient)

\begin{tabular}{lc}
\hline Variable & R-Square \\
\hline Consumer Satisfaction & 0,105 \\
\hline Source: Primary Data, 2020 &
\end{tabular}

The R-square of the consumer satisfaction variable is 0.105 , as shown in Table 5. It demonstrates that the variability of service quality, product image, and promotion variables is $10.5 \%$. According to the R-square value, the factors of service quality, product image, and promotion had a weak predictive effect on the buyer's character.

\subsubsection{Hypothesis Test}

Hypothesis testing also seeks to establish the validity of the claimed research or hypothesis. The $p$-value is used to calculate the correlation between constructs. In this study, the significance level was set at $5 \%$. If the p-value is greater than 0.05 , Ho is accepted; if the p-value is less than 0.05 , Ho is refused (Garson, 2016; Solimun et al., 2017). Here is the SEM structure model.

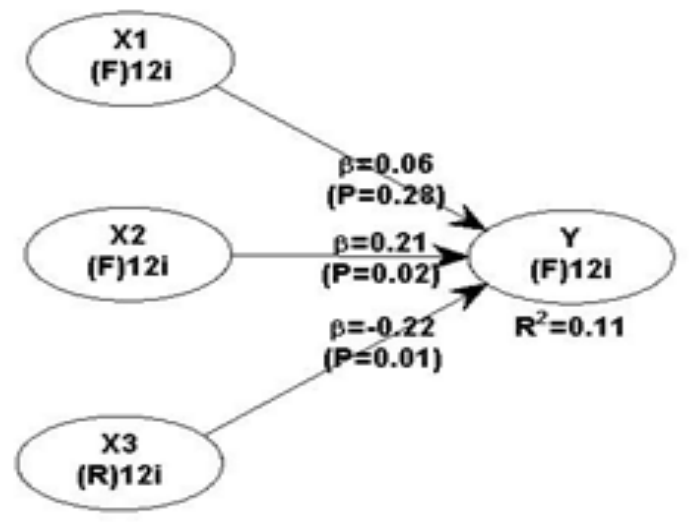

Figure 1. SEM Structure Model

1. Variable X1 (service quality) had no significant effect on variable $\mathrm{Y}$ (consumer satisfaction) because it had a p-value of 0.28 from 0.05 as the limits of its significance level. Variable X1 (service quality) also had a positive effect on variable $Y$ (consumer satisfaction), as seen by the path coefficient value of 0.28 . This number showed that if the service quality assessment (X1) increases by one unit, the measured consumer satisfaction will increase by 0.28 . On the other hand, every unit decrease in the assessment of service quality reduces the assessment of consumer satisfaction by 0.28 .

2. Variable X2 (product image) had a significant effect on variable $\mathrm{Y}$ (consumer satisfaction) because it had a p-value of 0.02 from 0.05 as the limits of its significance level. Variable X2 (product image) had a positive effect on variable $\mathrm{Y}$ (consumer satisfaction), as seen by the positive path coefficient value of 0.21 . This number illustrated that if the assessment of X2 (product image) increases by one unit, the assessed consumer satisfaction $(\mathrm{Y})$ increases by 0.21 . On the other hand, every unit decrease in the assessment of product image reduces the assessment of consumer satisfaction by 0.21 .

3. Variable X3 (promotion) had a significant effect on variable $Y$ (consumer satisfaction) because it had a p-value of 0.01 from 0.05 as the limits of the significance level. Variable X3 (promotion) had a positive effect on variable $\mathrm{Y}$ (consumer satisfaction), as indicated by the path coefficient value of -0.22 . This number illustrated that if the assessment of X3 (promotion) increases by one unit, the assessed consumer satisfaction (Y) 
increases by 0.22 . On the other hand, every unit decrease in the assessment of X3 (promotion) reduces the assessment of consumer satisfaction (Y) by 0.22 .

\section{Conclusion}

The majority of consumers in the Oro-Oro Dowo market Malang who use non-cash applications are mostly female with an age range of 20-25 years, the majority of education is at the high school level, the majority of job type is students with an average income of $<\mathrm{Rp}$. 2.000.000. Based on the PLS-SEM analysis, the R-square value obtained. It is known that the variables of service quality, product image, and promotion have weak predictive power on consumer satisfaction which is only $10.45 \%$. Pathcoefficient test revealed that service quality (X1) has no significant effect on consumer satisfaction because it has a significant value of $0.28(>0.05)$. Product image (X2) has no significant effect on consumer satisfaction because it has a significant value of $0.02(<0.05)$. Promotion (X3) has no significant effect on consumer satisfaction because it has a significant value of $0.01(<0.05)$.

\section{References}

Bayu, D. K., Ningsih, G. M., \& Windiana, L. (2020). Pengaruh Labelisasi Halal, Merek dan Harga Terhadap Keputusan Pembelian Pinuman Chatime. Jurnal Sosial Ekonomi Pertanian, 16(3), 239-256. https://doi.org/10.20956/jsep.v16i3.12403

Bayu, I., Ibrahim, J. T., Bakhtiar, A., \& Mufriantie, F. (2020). Analisis FaktorFaktor Yang Mempengaruhi Keputusan Membeli Komoditi Pertanian Di Pasar Tradisional Kepanjen Malang. Jurnal Agribest, 4(2), 108-122. https://doi.org/10.32528/agribest.v4i2.3547

Esselink, H., \& Hernández, L. (2017). The Use of Cash by Households in the Euro Area. ECB Occasional Paper No. 201, (201).

Garson, G. D. (2016). Partial Least Square: Regression \& Structural Equation Models. Asheboro, NC 27205 USA: Statistical Associates Publishing. https://doi.org/10.3726/978-3-0353-0280$6 / 8$

Gong, X., Zhang, K. Z. K., Chen, C., Cheung, C. M. K., \& Lee, M. K. O. (2020). Transition from web to mobile payment services: The triple effects of status quo inertia. International Journal of Information Management, 50(July 2019), 310-324. https://doi.org/10.1016/j.ijinfomgt.2019.08. 006

Hair, Joe F, Ringle, C. M., \& Sarstedt, M. (2011). PLS-SEM : Indeed a Silver Bullet PLS-S. Journal of Marketing Theory and Practice, 19(2), $37-41$. https://doi.org/10.2753/MTP10696679190202

Hair, Joseph F., Hult, G. T. M., Rigle, C. M., \& Sarstedt, M. (2014). A Premier on Partial Least Squares Structural Equation Modelling (PLS-SEM). (K. Koscielak, Ed.). Thousand Oaks, California 91320: SAGE Publications, Inc.

Harasim, J., \& Klimontowicz, M. (2017). Attitudes of Polish households towards cash payments. Europa Regionum. https://doi.org/10.18276/er.2017.30-02

Junaidi, A. (2015). Internet Of Things, Sejarah, Teknologi Dan Penerapannya: Review. Jurnal Ilmiah Teknologi Informasi, IV(3), 62-66.

https://doi.org/10.33197/jitter.vol1.iss3.201 5.66

Kalckreuth, U. von, Schmidt, T., \& Stix, H. (2014). Choosing and using payment instruments: evidence from German microdata. Empirical Economics, 46(3), 1019-1055. https://doi.org/10.1007/s00181013-0708-3

Lenzun, J. J., Massie, J. D. ., \& Adare, D. (2014). Pengaruh Kualitas Produk, Harga Dan Promosi Terhadap Kepuasan Pelanggan. Jurnal EMBA, 2(3), 1237-1245. Retrieved from

https://ejournal.unsrat.ac.id/index.php/emba /article/viewFile/5802/5335

Marphy, T., \& Priminingtyas, D. (2019). Analisis Faktor-Faktor yang Mempengaruhi Tingkat Partisipasi Petani Dalam Program Asuransi Usahatani Padi (AUTP) di Desa Watugede, Kecamatan Singosari, Kabupaten Malang. Habitat, 30(2), 62-70. https://doi.org/10.21776/ub.habitat.2019.03 0.2 .8

Maulana, S. M., Susilo, H., \& Riyadi. (2015). Implementasi E-Commerce Sebagai Media Penjualan Online. Jurnal Administrasi 
Bisnis, 29(1), 1-9. Retrieved from http://administrasibisnis.studentjournal.ub.a c.id/index.php/jab/article/view/1165/1452

Maulinda, D. G. (2016). Analisis Trust dalam Penggunaan E-Money sebagai Teknologi Konsumsi : Studi Mengenai Pengguna EMoney Kelas Menengah-Atas dan Menengah- Bawah Mahasiswa Fakultas Ilmu Sosial dan Ilmu Politik Universitas Indonesia. Indonesian Journal of Sociology and Education Policy, 1(1), 1-79. https://doi.org/10.21009/10.21009/ijsep.011 .04

Meyer, A. (2015). Heterogeneity in the preferences and pro-environmental behavior of college students: the effects of years on campus , demographics, and external factors. Journal of Cleaner Production. https://doi.org/10.1016/j.jclepro.2015.10.13 3

Polasik, M., \& Piotrowski, D. (2016). Payment Innovations in Poland: the Role of Payment Services in the Strategies of Commercial Banks. Ekonomia i Prawo. Economics and Law, 15(1), 73-101. https://doi.org/10.12775/eip.2016.006

Purnomo, M., Utomo, M. R., Pratiwi, V. A., Laili, F., Pariasa, I. I., Riyanto, S., ... Handono, S. Y. (2021). Resistance to mining and adaptation of Indonesia farmer's household to economic vulnerability of small scale sand mining activities. Local Environment: The International Journal of Justice and Sustainability, 26(12), 1-14. https://doi.org/10.1080/13549839.2021.199 0234

Putra, A. S. (2015). Pengaruh Corporate Social Responsibility Terhadap Profitabilitas Perusahaan (Studi Empiris pada Bursa Efek Indonesia Tahun 2010-2013 ). Jurnal Nominal, $\quad \operatorname{Vol.IV}(2), \quad 88-110$. https://doi.org/10.21831/nominal.v4i2.8002

Rifai, A. (2015). Partial Least Square-Structural Equation Modeling (PLS-SEM) untuk mengukur ekspektasi penggunaan repositori lembaga: Pilot studi di UIN Syarif Hidayatullah Jakarta. Al-Maktabah, 14(1), 56-65.

Roberts, J. A. (1996). Green consumers in the 1990s: Profile and implications for advertising. Journal of Business Research,
36(3),

217-231.

https://doi.org/10.1016/0148-

2963(95)00150-6

Rogers, E. M. (1995). Diffussion of Innovations (4th ed.). New York: Free Press.

Schubert, F., Kandampully, J., Solnet, D., \& Kralj, A. (2010). Exploring Consumer Perceptions of Green Restaurants in the US. Tourism and Hospitality Research, 10(4), 286-300. https://doi.org/10.1057/thr.2010.17

Shin, J., Song, M., Hafeez, H., Jeusraj, P. J., Kim, D. H., Lee, J. C., ... Ryu, S. Y. (2019). Harvesting near- and far-field plasmonic enhancements from large size gold nanoparticles for improved performance in organic bulk heterojunction solar cells. Organic Electronics, 66, 94-101. https://doi.org/10.1016/j.orgel.2018.12.024

Shodiq, W M, Relawati, R., \& Bakhtiar, A. (2020). Education of Rural Society Influences Green Behaviour in Disposing Food Packaging. Quantum Journal of Social Sciences and Humanities, 1(1), 30-42. Retrieved from http://qjssh.com/index.php/qjssh/article/vie $\mathrm{w} / 8 / 4$

Shodiq, Wahid Muhammad, Relawati, R., \& Bakhtiar, A. (2020). Implementasi Kepedulian Lingkungan dalam Pembelian Makanan Kemasan. Agriecobis (Journal of Agricultural Socioeconomics and Business), 3(2), $58-65$. https://doi.org/10.22219/agriecobis.Vol3.No $2.58-65$

Sholiha, E. U. N., \& Salamah, M. (2015). Structural Equation Modeling-Partial Least Square untuk Pemodelan Derajat Kesehatan Kabupaten/Kota di Jawa Timur (Studi Kasus Data Indeks Pembangunan Kesehatan Masyarakat Jawa Timur 2013). Jurnal Sains Dan Seni ITS, 4(2), 169-174. https://doi.org/10.12962/j23373520.v4i2.10 443

Solimun, Fernandes, A. A. R., \& Nurjannah. (2017). Metode Statistika Multivariat Pemodelan Persamaan Struktural (SEM) Pendekatan WarpPLS (4th ed.). Malang: Universitas Brawijaya Press. Retrieved from https://books.google.co.id/books?id=GrRV DWAAQBAJ

Suminar, R. (2017). Pengaruh Kualitas Layanan 
Terhadap Kepuasan Konsumen

Hypermarket. Sekretari, 4(1), 28.

https://doi.org/10.32493/skr.v4i1.605

Swiecka, B., \& Grima, S. (2019). Factors Affecting the Consumers' Choice of Payment Instrument in Poland. European Research Studies Journal, XXII(4), 179-198. https://doi.org/10.35808/ersj/1505

Swiecka, B., Terefenko, P., \& Paprotny, D. (2021). Transaction factors' influence on the choice of payment by polish consumers. Journal of Retailing and Consumer Services, $58($ July 2020). https://doi.org/10.1016/j.jretconser.2020.10 2264

Tangguh, G. G., Pangestuti, E., \& Nuralam, I. P. (2018). Pengaruh Citra Merek, Kualitas Layanan, dan Harga Terhadap Kepuasaan Pelanggan Go-Ride. Jurnal Administrasi Bsinis, 61(2), 118-126.

Tazkiyyaturrohmah, R. (2018). Eksistensi Uang Elektronik Sebagai Alat Transaksi Keuangan Modern. Muslim Heritage, 3(1). https://doi.org/10.21154/muslimheritage.v3i 1.1240

Widi, R. (2011). Uji Validitas Dan Reliabilitas Dalam Penelitian Epidemiologi Kedokteran Gigi. Stomatognatic - Jurnal Kedokteran Gigi, 8(1), 27-34. Retrieved from https://jurnal.unej.ac.id/index.php/STOMA/ article/view/2083

Windiana, L., Bakhtiar, A., Kurniasih, V., \& Basamah, S. (2020). The Effect of Green Marketing toward the Consumers Buying Interest of Starbucks Coffee Mediated By Brand Image. Habitat, 31(1), 36-41. https://doi.org/10.21776/ub.habitat.2020.03 1.1 .4

Zhou, T. (2013). An empirical examination of continuance intention of mobile payment services. Decision Support Systems, 54(2), 1085-1091.

https://doi.org/10.1016/j.dss.2012.10.034 